This is authors' self-archived version that may differ in many parts from the final article. The final version of the article can be found at: http://dx.doi.org/10.1504/IJTMKT.2013.054081

Please use and refer to the final version of the article only, thank you!

Aarikka-Stenroos L \& Lehtimäki T (2013). Building up a firm's commercialisation competence: from

product concept to the first reference. International Journal of Technology Marketing 8(2), 177-196.

\title{
Building up a firm's commercialisation competence: from product concept to the first reference
}

\section{Leena Aarikka-Stenroos}

Department of Marketing and International Business

Turku School of Economics, University of Turku

Address: Turku School of Economics, FI-20014 University of Turku, Finland

E-mail: leena.aarikka-stenroos@utu.fi

Fax: +35823338900

\section{Tuula Lehtimäki}

Department of Marketing

Oulu Business School, University of Oulu

Address: P.O. Box 4600, FI-90014 University of Oulu, Finland.

E-mail: tuula.lehtimaki@oulu.fi

\begin{abstract}
This study examines the build-up of commercialisation competence when a firm moves from concept development to the first customer reference. During this period substantial learning on commercialisation occurs as the firm develops an understanding of the fit between the business environment and the new product, which helps the firm improve its strategic marketing decisions. This process builds the innovator firm's commercialisation competence which makes it possible for the firm to succeed in acquiring the first reference. The study draws on the literature on innovation management concerning innovation competence, commercialisation of innovations, and reference marketing. Employing qualitative multiple case analysis, this study generates a dynamic model for commercialisation competence build-up and identifies strategic marketing, market preparation/creation and sales creation as key competence groups for commercialisation with a total of fourteen sub-competences. The developed framework serves as a managerial tool to determine critical steps in commercialisation and the required commercialisation competences.
\end{abstract}

Keywords: commercialisation competence; product concept; first reference; learning; 
commercialisation process; innovation process; innovation management; radical innovations; case study; technology marketing.

\section{Biographical notes:}

Dr. Leena Aarikka-Stenroos is a Senior Researcher at the Department of Marketing and International Business, Turku School of Economics, Finland. Her research focuses on the commercialization of innovations, service business and the role of networks in innovation and service businesses. Her articles have been published in e.g. Industrial Marketing Management, Journal of Business Research and international books.

Tuula Lehtimäki is a doctoral candidate at Oulu Business School, Finland. Her research interests include new industrial product launching, commercialisation, cross-functional integration, and innovation management. She is published in e.g. Industrial Marketing Management.

\section{Introduction}

Commercialisation is a critical area of the innovation process, mainly because of the high risks and investments that it brings with it (Chiesa and Frattini, 2011). Even though a meta-analysis of the new product literature indicates that the most of the factors impacting success of the new products are controllable by management (Di Benedetto, 1999), many companies too often just hope for the best and do not spend enough money or expend enough effort on commercialisation planning and management. Consequently, despite being technically and functionally superior to competing offerings, many new products fail mainly because of a poor launch and commercialisation (Di Benedetto, 1999; Chiesa and Frattini, 2011). The timing, number of markets and number of segments are key commercialisation issues to consider but most firms have problems with them (Nevens, 1990). Despite the challenges of commercialisation, it is often the least well managed phase of the entire innovation process (Chiesa and Frattini, 2011).

Success with an innovation, however, does not often come directly and through wisely pre-determined decisions but through accidental and active learning; in such cases, the innovation process involves cycles of learning (Steen $e t$ al., 1998) and can be considered an "innovation journey" comprising episodes of failure and success (e.g., Garud et al., 2011). Bringing an innovation to market is in a way similar to technology marketing. Technology marketing refers to finding ways to optimize technology potential at the market, which requires a broad approach to considering in-house development and external commercialisation opportunities, target groups, market segments and marketing instruments (e.g., Tschirky, Escher and Tokdemir, 2000; Lichtenthaler, 2006). High technology marketing, especially, tends to be a longitudinal and iterative process by nature, where certain tasks are repeated with differing emphases as the market is gradually being prepared (Easingwood and Harrington, 2002), and applications for the technology are developed to fit the market (Jolly, 1997). Matching technological capabilities to market opportunities is a key element of an innovation process (Freeman, 1982), which applies to generic (Maine and Garnsey, 2006) and radical innovations (O'Connor and Veryzer, 2001) alike. Innovativeness creates uncertainties, as the firm bringing an innovation to market often needs to stretch its competences and learn to understand an unfamiliar market (McDermott and O'Connor, 2002). Uncertainty can be tackled by an iterative approach (Chen, Reilly and Lynn, 2012). In commercialising innovations, it can be expected that the firm will not get it right first time (Lynn et al., 1998), and therefore needs to probe and learn its way into the market (Lynn, Morone and Paulson, 1996).

Hence, our assumption is that in order to be able to manage commercialisation, firms need to understand this evolving nature of the commercialisation process, especially when innovations are brought to market. We suggest that not only $\mathrm{R} \& \mathrm{D}$ but also the commercialisation facet of the innovation process calls on particular competence that is developed during the process. A competence refers to the knowledge, skills, and related routines that constitute a firm's ability to create and deliver superior customer value (Day, 1994). In other words, competencies are realized in behaviour processes that engender procedural knowledge or skill on how to do something (Kogut and Zander, 1992), and are developed through path dependent learning processes (Henderson and Cockburn, 1994). Accordingly, in this study, commercialisation competence refers to the knowledge, skills and routines that contribute to successful 
commercialisation. This study posits that the innovator firm needs to learn the relevant commercialisation activities and how they are interrelated in order to succeed in commercialisation and to build up its commercialisation competence. Hence, it suggests that commercialisation is not a linear process; commercialisation activities evolve and elaborate as the innovator faces critical incidents, reacts to them and through trial and error learns to commercialise the product.

Commercialisation in this study refers to a cross functional process that captures the innovator firm's efforts to realize the full benefits of the new product for the customer, including activities from early development to market acceptance (e.g., Athaide et al., 1996; Jolly, 1997), moving the new product to a profit-making position (Siegel et al., 1995). Commercialisation can be measured by the achievement of the first sale (e.g., Nerkar and Shane, 2007), but here the first reference is considered a more critical step in commercialisation, since it requires a successful delivery and brings with it important credibility for creating sales (e.g., Ruokolainen, 2008; Tolstoy and Angdal, 2010). If the product is innovative and the adoption barriers are high, getting the first customer to adopt the product and to agree to be used as a reference is even more difficult but also more crucial. We assume that the development of commercialisation competence makes it possible for the firm to succeed in acquiring the first reference customers and thus gain acceptance from market players.

Commercialisation studies, however, have not focused on competence building, even though it has been implied in commercialisation models applying the idea of nonlinearity and repeatable activities. For example, Jolly (1997) suggests that moving between the sub-processes of commercialisation requires the successful accomplishment of the bridging activities. Research on divergent competences has suggested conceptualisations that can be linked to commercialisation competence, but has not discussed commercialisation competence in particular. Atuahene-Gima (2005) elaborates innovation competence, but does not focus on commercialisation. Katzy and Crowston (2008) discuss competency rallying for technical innovation, referring to the identification and development of competences and market opportunities, and marshalling them through collaboration between firms. Reid and de Brentani (2010) present market visioning competence as a set of individual and organisational capabilities that enable advanced technologies to be linked to a future market opportunity; this competence includes networking, idea driving, proactive market orientation and market learning tools. A few studies mention commercialisation competence but do not focus on it or define it further. Story et al. (2011) analyse radical innovation competence and even identify commercialisation competence but do not discuss it further. Perks and Moxey (2011) analyse how firms develop innovation and commercialisation capabilities through collaboration in networks but do not focus on commercialisation. Chen (2009) discusses a particular technology commercialisation competence referring to "competence of firms to use technologies in products across a wider range of markets, incorporate a greater breadth of technologies in products, and get products to market faster", but does not analyse commercialisation competence at a more general level.

Thus, a research gap remains concerning how the commercialisation process transforms and develops over time and, especially, how commercialisation competence is built. Therefore, this study examines the commercialisation process and focuses on how innovator firms develop their commercialisation competence when they move from concept development to acquiring the first customer reference. Our first research question is what is the nature of the commercialisation process when the firm moves from concept development to acquiring the first customer reference? As commercialisation requires the management of divergent marketing tasks, and making a multitude of linked strategic and tactical decisions (Hultink et al., 1997; Di Benedetto, 1999), presumably the innovator firm needs to learn a variety of lessons. Hence, firms build up their commercialisation competence during the dynamic commercialisation process. Our second research question is therefore what competences do firms develop for commercialisation, i.e. what subcompetences comprise commercialisation competence?

This study is a qualitative case study that employs multiple sourcing as a data gathering method. We present four cases that enable valuable detailed description of different learning processes structured with framework and comparison of cases. In all the cases, European firms have developed the innovations and targeted them at international b-to-b or bto-c markets. The cases demonstrate how trials, errors and partial successes shape innovators' future actions, and how commercialisation competence is composed through learning. Since different kinds of innovation and context require different kinds of commercialisation activity (e.g., Nagle, 2005) and decision (Hultink et al., 1997), it can be assumed that the type of commercialisation competence depends on the context, too. Therefore, we also take in the context of commercialisation, especially in the empirical part of the study.

This study generates new understanding on the dynamics of the commercialisation process, commercialisation competence and its build-up. In terms of practical implications, our findings show how managers within innovator firms can build commercialisation competence and indicate which subjects and aspects of commercialisation they need to be willing to learn. The paper is structured as follows. First, we discuss through a literature analysis the commercialisation process and what kind of competence successful commercialisation may require. We also examine the effects of 
innovation context on commercialisation and a firm's efforts in gaining the first customer references. On this basis, we build a framework for building up commercialisation competence. Then we present our research methods, cases and the results gained. Finally, we conclude with theoretical contribution and limitations and offer some managerial insights.

\section{Commercialisation competence build-up during the commercialisation process}

\section{Linking the innovation journey and competence build-up features to commercialisation}

Garud et al. (2011) show how learning, trial and error have shaped several firms' innovation journeys over time, and their findings demonstrate that what appeared to be false starts or dead ends in real time served as the foundation for innovation over time. Failures are powerful learning stimuli (Garud and Karnøe, 2001), and Steen et al. (1998) identify cycles of learning within the innovation process. Nonlinearity in the innovation process may also complicate the journey; what might be considered a good solution in real time may generate unintended problems later on (Garud et al., 2011). Thus, innovators often face not only progression but also regressions and loops embedded within the process.

Commercialisation competence may build on the journey through trial and error if corrective measures are taken based on the developed understanding of the fit between the business environment, the product concept and the business model. Sometimes innovating firms need to unlearn existing conventions in doing business (Garud and Karnøe, 2001; Aarikka-Stenroos and Sandberg, 2012). Consequently, fully formed plans and visions on how to commercialise a product are not preconditions for success; instead, plans and visions emerge and evolve along the commercialisation process as commercialisation competence is accumulated. In order to succeed in commercialisation, the innovator firm needs to know the driving forces that impact innovation success in the specific situation (e.g., Easingwood et al., 2006; Chiesa and Frattini, 2011). Guiltinan (1999) suggests a feedback loop from the development stage to the marketing strategy; the product positioning and market selection decisions may need rethinking if a manager believes that the firm cannot complete the commercialisation activities required for market acceptance. Strategic orientations facilitate adaptation to market conditions and the match between firm strategy and resource endowment, but organizational learning mediates the positive effects of strategic orientations on new product commercialisation, namely new product advantage, new product innovativeness, and the number of new products introduced (Mu and Di Benedetto, 2011).

\section{Relevant tasks of commercialisation}

Commercialisation often refers to the final phase of an innovation process (e.g., Buckler, 1997), introducing the innovation to the market. Crawford (1997) considers commercialisation to start much earlier, when management commits to a new concept. According to Jolly (1997), commercialisation starts even before that, because the commercial aspects of the innovation need to be considered from the beginning of the innovation process. This study follows a logic similar to Jolly (1997) in conceptualising the commercialisation process; he presents a process comprising five sub-processes, i.e. task groups, which are bridged by activities and resources that secure the commitment and satisfaction of the relevant stakeholders, so that moving to the next task group is possible. These tasks involved in the commercialisation process as outlined here are now briefly discussed.

The first task group is imagining the techno-market insight, which refers to identifying and bringing forward a technological discovery linked to a market opportunity (Jolly, 1997). Mobilising interest of the relevant stakeholders, especially of the management, is a prerequisite for getting the resources for moving forward to the second task group, incubating the innovation's commercial potential (Jolly, 1997). At this point, a business case and a plan are created (Jolly, 1997). An understanding of customer desires within the target markets is required to develop product and service concepts meeting those desires, and to choose one or more concepts for commercialisation (Srinivasan et al., 1997). Strategic decisions, which create the basis for the latter tactical decisions, are made early in the process and address product strategy, market strategy, timing, and competitive and firm strategy (Hultink et al., 1997). Thus, decision making on commercialisation is linked and coupled, and some decisions are more easily modified later than others (Hultink et al., 1997). Convincing presentation of the innovation's market potential is especially important for small firms and lone inventors, who need external investors in order to move forward and to mobilise the resources that are needed to demonstrate the innovation (Jolly, 1997).

Hence, the third task group is demonstrating the innovation and its benefits in different contexts in order to mobilise key market constituents that are needed for gaining market acceptance and delivering the benefits of the innovation (Jolly, 1997). Typically a variety of external relational resources are utilised to accelerate the innovation's path from ideas to eventual market introduction (Story, Hart and O’Malley, 2009). The relevant stakeholders include not only potential 
customers, but also the firm's organisation, dealers, other suppliers and competitors (Jolly, 1997; Talke and Salomo, 2009; Talke and Hultink, 2010a; Aarikka-Stenroos and Sandberg, 2012). When the innovation affects a broad set of actors in the market, that whole network needs to be convinced by the innovation in order to create adoption (Corkindale, 2010). And in order to achieve that, the innovator needs to understand the interests of each specific stakeholder group. Mobilising the relevant stakeholders is essential in gaining market acceptance and overcoming adoption barriers (Jolly, 1997; Bunn et al., 2009; Talke and Salomo, 2009), especially under conditions of high uncertainty (Talke and Hultink, 2010a). For an innovative product, the audience is often sceptical (Jolly, 1997). High adoption barriers stem from reasons such as an innovative product, conservative market, high investment costs, trust-sensitive industry, and high technological risk. The innovator firm must work to overcome the resistance of end users, intermediaries and complementors (cf. Talke and Salomo, 2009; Chiesa and Frattini, 2011).

At this point, the firm needs to build awareness, establish credibility and trust, communicate usability and benefits, organise distribution and trials, and create product support offerings (Aarikka-Stenroos and Sandberg, 2012). Decisions on pricing, product assortment, branding, promotion and distribution need to be made before launch (Hultink et al., 1997). Accordingly, marketing material and program development, sales channel development, training, and service and support development are relevant commercialisation tasks at this point (PDMA, 2004, p. 578). Hence, parallel to the technical development activities within the demonstration task group, the innovator firm needs to develop its understanding of the true customer benefits of the innovation and base its marketing communication plans on these insights. The customer can be convinced both of the benefits of the innovation and of the innovator's ability to deliver it by communicating and concretising the firm's technological and customer related knowledge (Lehtimäki et al., 2009). The seller can gather information on product performance in the customers' processes (Athaide et al., 1996), to demonstrate the benefits of the innovation. The demonstration context needs to be relevant to the customers, because it's the customers who will evaluate the relative advantage of the innovation (Rogers, 1983; Athaide et al., 1996; Jolly, 1997).

As the key constituents are successfully mobilised, and the innovation has been launched to the market, the fourth task group, promoting adoption, can be executed in order to increase the market share (Jolly, 1997). Adoption tends to be faster for innovations that appear to be easy to understand and use, are easily testable, have observable benefits, and are compatible with previously introduced ideas and the needs of the potential adopters (Rogers, 1983). Utilising references in marketing communication answers to those requirements. Customer references are deployed particularly in b-to-b markets to enhance credibility when introducing new products (Salminen and Möller, 2006), and especially for innovative products with a high perceived technical risk and learning curve (Athaide et al., 1996), and also when the firm is new (Rehme and Svensson, 2011). The first customer reference for an innovation is a source of learning, a technology test-bench, and a powerful promotional tool increasing the seller's and the innovation's creditability (Ruokolainen and Igel, 2004; Rehme and Svensson, 2011). Reference customers can also be considered as early adopters that may facilitate commercialisation by speeding diffusion, as they create the impression for other potential adopters of a critical mass of adopters and users (see Van Slyke et al., 2007). The first sale does not necessarily lead to the acquisition of the first customer reference. That sale must be a success and the customer willing and committed to act as a reference for use in further sales (Ruokolainen and Igel, 2004; Ruokolainen, 2008). Success in acquiring the first reference is not dependent solely on the activities of the innovator firm. Successful commercialisation means not only stimulating adoption but also achieving successful implementation of the innovation at the customer end (Athaide et al., 1996). Reference customers are as early adopters often enthusiastic with high expectations of a new product, and may quickly become dissatisfied if the product's performance does not meet expectations (see Chiesa and Frattini, 2011). If a reference fails, it can be decisive to the success of the innovation since it is thereafter more difficult to sell (Ruokolainen and Igel, 2004).

Within the context and scope of this study, promoting task group would mark the end point of the examination, signalling the initiation of adoption in the market and thus also acquisition of the first successful customer reference. Next, the complementary assets for delivery would need to be mobilised for sales to take off, so that the process would move to sustaining commercialisation (Jolly, 1997).

\section{Synthesis: Building up commercialisation competence}

The findings discussed with regard to commercialisation, reference marketing, innovation management and competence studies are brought together in Figure 1, which presents an a priori framework for the build-up of commercialisation competence, illustrates the broad range of parallel commercialisation tasks, and the interplay between the strategic, commercial, technical and operational perspectives (Prebble et al., 2008). 
The commercialisation competence build-up is entwined with the commercialisation process task groups, as the competence build-up is considered here to occur through trial and error during the commercialisation process (indicated by the curved arrows in Figure 1). By developing a fit between the commercialisation tasks, the features of the innovation, the features of the firm, and the features of the market, the firm builds the commercialisation competence needed to acquire the first customer reference for the innovation. Hence, the company's internal and external context and the characteristics of the innovation affect commercialisation in many ways (e.g., Guiltinan 1999). For example, if the innovation concerns a very new concept and the market is still an emerging field, the innovator firm's activities and tasks, ideas and required partners for collaboration are often indeterminate and vague (e.g., Möller and Rajala, 2007). In a context of that nature, it can be assumed that the required commercialisation tasks and competence are also blurred and complex, and considerable effort would need to be expended in building up commercialisation competence. Similarly, organisational characteristics, such as the size (Kuester, Homburg and Hess, 2012) and mindset of the firm (Talke and Hultink, 2010b), and innovation characteristics, such as the newness of the innovation concept (e.g., Talke and Salomo, 2009), and its complexity (Talke and Hultink 2010a; Kuester, Homburg and Hess, 2012), affect the set of essential commercialisation activities. Thus, the innovation context is described here through the characteristics of the markets, the innovator firm and the innovation.

The dynamics of the commercialisation process and commercialisation competence build-up are examined in more detail through a qualitative case study, which is presented next.

\section{Methodology}

\section{Research design: multiple case study and data gathering}

The empirical part of the study is a multiple case study that describes and analyses the commercialisation activities and the commercialisation competence build-up. Case study strategy is chosen because it facilitates a holistic understanding of complex phenomena that are not easily separable from their context (cf. Yin, 1989). Case study research maximizes the realism of the context at the expense of generalizability (McGrath, 1982). The multiple cases enable both valuable and detailed descriptions of diverse commercialisation paths, with diverse problems, and a comparison of the cases. In each case (Table 1), a Finnish firm developed an innovation that differed substantially from the firm's existing products, and targeted it at international (b-to-b and b-to-c) markets. The innovations are new for both the firms and markets. It is assumed that in such a situation firms experience learning and need to develop their commercialisation competence, which is why the particular cases were selected.

\section{INSERT TABLE 1 HERE, PLEASE}

The study is longitudinal in nature and relies on both retrospective data and real-time observation and interviews. The primary dataset includes semi-structured interviews with representatives in the focal organizations, and with other key actors. Telephone discussions and e-mail correspondence were used to complete the interviews. The secondary dataset includes extensive archival internal and media originated data, such as technical documents, marketing brochures, books chronicling firms' history, company reports, newspaper articles, and webpages concerning the product, the company and the focal markets. All the datasets covered the following: 1) the characteristics of the innovation; 2) the whole innovation process; 3 ) the actors and tasks in the commercialisation; 4) the emerged challenges/critical incidents/mistakes; and 5) the lessons learned.

\section{Analysis}

Within-case analysis was conducted for each case, followed by cross-case analysis. The first step in the within-case analysis was to classify the data in the form of a chronological listing of events, and to identify the commercialisation competence development paths and critical incidents that impacted commercialisation and the development of commercialisation competence and relevant sub-competences. We also analysed who was involved in the learning process, what kind of events triggered the development of commercialisation competences, and how the features of the product, firm and markets impacted the relevant commercialisation tasks.

The data were then organized into themes and cross-case analysis was conducted by comparing different commercialisation tasks, emerged challenges, and developed commercialisation competences. In comparing commercialisation and learning paths, we identified aspects that innovator firms learned or would have needed to learn, and we conceptualised these emergent themes into commercialisation sub-competences. Cross-case analysis revealed the 
specialty of each case but also general commercialisation paths that were common to all cases. Comparison thus showed how cases varied in terms of commercialisation tasks, paths and competences. However, similar commercialisation competences were identified across the cases even though the set of commercialisation sub-competences differed within a specific case. As a result of the comparison, we integrated the knowledge on the commercialisation process and were able to construct a more generalised and conceptualised model for commercialisation competence build-up. Data triangulation (multiple data sources) and researcher triangulation (multiple researchers) helped to enhance the trustworthiness of the results.

\section{Findings and discussion}

Table 2 presents the short case synopses and key results driven by the analysis of the commercialisation process and commercialisation sub-competences. All cases demonstrate commercialisation and learning paths, and show what kind of commercialisation competences are developed or aimed to be developed during the divergent commercialisation process phases.

\section{INSERT TABLE 2 HERE, PLEASE}

Next, the knowledge driven by the cases is discussed employing the elements of the framework and the key findings are conceptualised. The comparison of the cases revealed that the commercialisation process is often non-linear with loops. During the process, many commercialisation tasks need to be redefined and decision making on marketing strategy and tactics refined. Firms aim to modify their ideas, concepts, plans, activities, and targets according to feedback they receive from markets (e.g. from customers, and other stakeholders such as distributors, complementors). Through trial and error the firms learn to:

- Adapt their marketing strategy and commercialisation tasks to the market and firm resources. A combined understanding of the market, the characteristics of the innovation and the firm is combined into a refined concept for a suitable target market. The firms needed to, for example, learn away from a product or sales orientation, learn market orientation, and fit the innovation into the firm's existing business and product range.

- Identify, demonstrate and communicate the benefits of the innovation from the customers' and other stakeholders' perspective, so that benefits can be turned into sales arguments.

- Identify the multiple antecedents for adoption among customers and stakeholders.

- Build the credibility of the innovation and the firm to overcome the identified adoption barriers in order to facilitate, ensure and speed adoption, and to create demand; to educate markets and collaborate with relevant actors.

- Identify, involve and mobilise the relevant stakeholders in the market to support commercialisation, acquisition of first references, and market creation. The ecosystem with distributors and complementaries can create new business fields, and stakeholders can perform commercialisation tasks such as education and benefit demonstration.

- Create sales and growth through making their first sales, acquiring the first reference customers, involving early adopters as reference customers, and utilising them in sales.

Thus, by identifying these important steps in the commercialisation process, the study discovered three key competence groups divided into several sub-competences that together comprise commercialisation competence (Figure 2). Some of the competences appear especially relevant in concept development and making strategic marketing decisions, whereas other competences are related to communicating and demonstrating the benefits of the innovation, or to acquiring the first customer references. In addition, some of the identified competences appear to be linked to the buildup of some other competence. These findings can be elaborated further to capture better the iterative nature of the commercialisation process and the linkages between the commercialisation task groups and the competencies.

\section{INSERT FIGURE 2 HERE, PLEASE}

\section{Conclusions}

This study presents a dynamic model for commercialisation competence build-up. First, we explored the process of how firms learn to commercialise and identified steps to build up commercialisation competence. Our study showed that 
commercialisation competence build-up is often complicated by the fact that the relevant commercialisation tasks may not be foreseeable or evident - this is often the case particularly if the innovation is new to the markets and/or to the firm. In such a situation, tasks and activities that lead to successful commercialisation may evolve step by step along the process. In other words, the innovator firm needs to cultivate intended commercialisation tasks according to feedback and critical incidents. If the firm learns from customer and other relevant stakeholder feedback, and adapts its activities accordingly, the firm can develop commercialisation activities that fit the characteristics of the innovation, the markets, and the resources of the innovator firm. Consequently, the firm can turn unsuccessful commercialisation activities into successful ones and thus build up its commercialisation competence.

Secondly, this study mapped commercialisation competence and identified several sub-competences that comprise it. Based on our findings, commercialisation competence can be defined to comprise the knowledge, skills and routines that contribute to 1) developing a profitable and realisable business model around the innovation; 2) understanding the antecedents of adoption in a particular market in order to focus on relevant commercialisation tasks and building credibility for the innovation and the innovator to enable market creation; and 3) creating and increasing sales. The buildup of these three key competence groups for commercialisation seems to be entwined in the progress of the commercialisation process. In fact, it appears that progress is related to the achievement of certain commercialisation sub-competences. What is important is that commercialisation competence cannot be developed solely internally - the development of commercialisation competence occurs through deep and open interaction with divergent stakeholders and through their feedback.

Based on these insights, a dynamic model for commercialisation competence build-up is proposed (Figure 3).

\section{INSERT FIGURE 3 HERE, PLEASE}

Figure 3 presents an elaborated model that illustrates the dynamics and elements of the commercialisation competence build-up. The circle in the middle represents a core issue in successful commercialisation and the build-up of commercialisation competence, namely the fit between the product concept and the marketing strategy based on market knowledge development, the benefit, and stakeholder identification. The further build-up is based on this strategic marketing competence group. The build-up of market creation and preparation competence and sales creation competence leads to the successful initiation of adoption. Even though the firm can experiment with sales along the commercialisation process, sales creation competence makes it possible to promote the adoption of the innovation in a way that succeeds not only in initiating adoption but also in increasing sales and achieving the market share targets later. Competence development might not occur in this order, but the illustration reflects which fundamental competences help build other competences.

As our first theoretical implication, the study conceptualised the dynamic and non-schematic model of the commercialisation process. Through multiple longitudinal case analyses we demonstrated the nature of the commercialisation process as the firm moves from concept development to acquiring the first customer reference. In identifying the four interrelated commercialisation task groups, and analysing the commercialisation process as a dynamic process including both partial failures and successes leading to learning, this study enriches and deepens the current knowledge on commercialisation (e.g., Jolly, 1997) that often presents commercialisation as either a successful or nonsuccessful linear process.

As our second theoretical implication, this study showed how, during the dynamic commercialisation process, firms build up and develop multiple commercialisation competences. We generated contribution by identifying and conceptualising three key competence groups with several sub-competences that help firms commercialise their innovations successfully. Commercialisation competences are built up when the firm reflects events, challenges, and feedback. So it may identify opportunities on how to manage commercialisation tasks and overcome commercialisation challenges and adoption barriers. By conceptualising commercialisation competence, our research elaborated the current knowledge on innovation competences (e.g., Story et al., 2011) and competences related to commercialisation (Perks and Moxey, 2011).

The developed framework also serves managerial implications. The dynamic model for commercialisation competence build-up helps to determine critical steps in the commercialisation process and the required commercialisation competence. For example, understanding the benefits of the innovation, identifying the stakeholders and developing market knowledge are important sub-competences for commercialisation, which cannot be overhauled in the commercialisation process. 
Moreover, the framework will help managers of innovator firms realise the dynamics of the commercialisation process, and analyse their experiences in commercialisation and the related competence development. Activities in the commercialisation process for innovations might be iterative and jump between experiments in sales and then back to concept development, which follows the idea of the required learning orientation but makes the commercialisation process complex and difficult to manage. However, if managers consider the path of the commercialisation competence build-up and not just pay attention to the completed commercialisation activities, they may understand the progress made from a different but important angle. Accordingly, the study may help managers purposefully develop and accumulate their commercialisation competence and diverse sub-competences.

\section{Limitations and further research}

Our cases do not represent all industries or firms, and studies on other industries may yield different answers concerning the commercialisation process and the competences. The examined firms were SM-sized which may accentuate a paucity of resources and need for supporting stakeholders. Large firms with a wide range of divergent products may face different commercialisation processes and needs for competences. Nevertheless, not all of the findings relate to issues specific to SMEs, so the findings are likely to be applicable to divergent firms and innovations. This research studied mostly radical innovations; less innovative products may lead to different kinds of finding.

Finally, we propose an agenda for future research. First, the process of the commercialisation competence build-up requires more attention, as the findings of this study suggest that the build-up might be path dependent. Second, the iterative nature of the commercialisation process for radical innovations is not thoroughly understood, even though it is acknowledged by several authors (Coviello and Joseph, 2013; Lynn et al., 1996). Therefore, the evolution and probing nature of the commercialisation process, per se, needs more research. Third, this study also raised the issue of how divergent stakeholders and their feedback impact the path of commercialisation and accumulation of commercialisation competence. Consequently future research could focus in greater depth on this aspect. Lastly, because the scope of this study was limited to the acquisition of the first customer reference, future research should also analyse how customer references can be employed further in the commercialisation process, e.g. how customer references facilitate increasing sales in the field of innovation. Then the important question is what are the particular competences that enable the firm to identify, acquire and employ customer references and thus to achieve success with an innovation.

\section{References}

Aarikka-Stenroos, L. and Sandberg, B. (2012) 'From new-product development to commercialisation through networks', Journal of Business Research, Vol. 65, No. 2, pp.198-206.

Athaide, G.A., Meyers, P.W. and Wilemon, D.L. (1996) 'Seller-buyer interactions during the commercialisation of technological process innovations', Journal of Product Innovation Management, Vol. 13, No. 5, pp.406-421.

Atuahene-Gima, K. (2005) 'Resolving the capability: Rigidity paradox in new product innovation', Journal of Marketing, Vol. 69, No. 4, pp.61-83.

Buckler, S.A. (1997) 'The spiritual nature of innovation', Research Technology Management, Vol. 40, No. 2, pp.43-47.

Bunn, M.D., Azmi, F. and Puentes, M. (2009) 'Stakeholder perceptions and implications for technology marketing in multi-sector innovations: The case of intelligent transport systems', International Journal of Technology Marketing, Vol. 4, No. 2/3, pp.129148.

Chiesa, V. and Frattini, F. (2011) 'Commercializing technological innovation: Learning from failures in high-tech markets', Journal of Product Innovation Management, Vol. 28, No. 4, pp.437-454.

Chen, C.-J. (2009) 'Technology commercialisation, incubator and venture capital, and new Venture performance', Journal of Business Research, Vol. 62, No. 1, pp.93-103.

Chen, J., Reilly, R.R. and Lynn, G.S. (2012) 'New product development speed: Too much of a good thing?', Journal of Product Innovation Management, Vol. 29, No. 2, pp.288-303.

Corkindale, D. (2010) 'Towards a business model for commercializing innovative new technology', International Journal of Innovation and Technology Management, Vol. 7, No. 1, pp.37-51.

Coviello, N. and Joseph, R. M. (2013, Forthcoming). 'Creating major innovations with customers: insights form small and young technology firms', Journal of Marketing. In press.

Crawford, C.M. (1997) New Products Management, Chicago: Irwin, a Times Mirror Higher Education Group.

Day, G.S. (1994) ‘The capabilities of market-driven organizations', Journal of Marketing, Vol. 58, No. October, pp.37-52.

Di Benedetto, C.A. (1999) 'Identifying the key success factors in new product launch', Journal of Product Innovation Management, Vol. 16, No. 6, pp.530-544.

Easingwood, C. and Harrington, S. (2002) 'Launching and re-launching high technology products', Technovation, Vol. 22, No. 11, pp.657-666. 
Easingwood, C., Moxey, S. and Capleton, H. (2006) 'Bringing high technology to market: Successful strategies employed in the worldwide software industry', Journal of Product Innovation Management, Vol. 23, No. 6, pp.498-511.

Freeman, C. (1982) The Economics of Industrial Innovation, London: Frances Pinter Publishers Ltd.

Garud, R., Gehman, J. and Kumaraswamy, A. (2011) 'Complexity arrangements for sustained innovation: Lessons from 3M corporation', Organization Studies, Vol. 32, No. 6, pp.737-767.

Garud, R. and Karnøe, P. (2001) 'Path creation as a process of mindful deviation', in R. Garud and P. Karnoe (Eds.) Path Dependence and creation, Mahwah: Lawrence Earlbaum and Associates Publishers, pp.1-38.

Guiltinan, J.P. (1999) 'Launch strategy, launch tactics, and demand outcomes', Journal of Product Innovation Management, Vol. 16, No. 6, pp.509-529.

Henderson, R. and Cockburn, I. (1994) 'Measuring competence? Exploring firm effects in pharmaceutical research', Strategic Management Journal, Vol. 15, No. Winter Special Issue, pp.63-84.

Hultink, E.J., Griffin, A., Hart, S. and Robben, H.S.J. (1997) 'Industrial new product launch strategies and product development performance', Journal of Product Innovation Management, Vol. 14, No. 4, pp.243-257.

Jolly, V.K. (1997) Commercializing New Technologies, Boston: Harvard Business School Press.

Katzy, B.R. and Crowston K. (2008) 'Competency rallying for technical innovation: The case of the Virtuelle Fabrik', Technovation, Vol. 28, No. 10, pp.679-692.

Kogut, B. and Zander, U. (1992) 'Knowledge of the firm, combinative capabilities and the replication of technology', Organization Science, Vol. 3, No. August, pp.383-397.

Kuester, S., Homburg, C. and Hess, S.C. (2012) 'Externally directed and internally directed market launch management: the role of organizational factors in influencing new product success', Journal of Product Innovation Management, Vol. 29, No. S1, pp.3852 .

Lehtimäki, T., Simula, H. and Salo, J. (2009) 'Applying knowledge management to project marketing in a demanding technology transfer project: Convincing the industrial customer over the knowledge gap', Industrial Marketing Management, Vol. 38, No. 2, pp.228-236.

Lichtenthaler, U. (2006) 'External technology commercialisation as an alternative mode of technology marketing', International Journal of Technology Marketing, Vol. 1, No. 4, pp.411-430.

Lynn, G.S., Mazzuca, M., Morone J.G. and Paulson A.S. (1998) 'Learning is the critical success factor in developing truly new products', Research Technology Management, Vol. 41, No. 3, pp.45-51.

Lynn, G.S., Morone, J. G., and Paulson, A. S. (1996) 'Marketing and discontinuous innovation: the probe and learn process', California Management Review, Vol. 38, No. 3, pp.8-37.

Maine, E. and Garnsey, E. (2006) 'Commercializing generic technology: The case of advanced materials ventures', Research Policy, Vol. 35, No. 3, pp.375-393.

McDermott, C.M. and O'Connor, G.C. (2002) 'Managing radical innovation: an overview of emergent strategy issues', Journal of Product Innovation Management, Vol. 19, No. 6, pp.424-438

McGrath, J.E. (1982) 'Dilemmatics. The study of research choices and dilemmas', in: J.E. McGrath, J. Martin, and R.A. Kulka (Eds.) Judgement Calls in Research, Beverly Hills: Sage Publications, pp.69-102.

$\mathrm{Mu}$, J. and Di Benedetto, C.A. (2011) 'Strategic orientations and new product commercialisation: Mediator, moderator, and interplay', $R \& D$ Management, Vol. 41, No. 4, pp.337-359.

Möller K. and Rajala A. (2007) 'Rise of strategic nets - New modes of value creation', Industrial Marketing Management, Vol. 36, No. 7, pp.895-908.

Nagle, S. (2005) 'Managing new product and service launch', in: K.B. Kahn, G. Castellion, A. Griffin (Eds.) PDMA Handbook, New Jersey: John Wiley \& Sons.

Nerkar, A. and Shane, S. (2007) 'Determinants of invention commercialisation: An empirical examination of academically sourced inventions', Strategic Management Journal, Vol. 28, No. 11, pp.1155-1166.

Nevens, T.M. (1990) 'Commercializing technology: what the best companies do', Planning Review, Vol. 18, No. 6, pp.20-25.

O'Connor, G.C. and Veryzer, R.W. (2001) 'The nature of market visioning for technology-based radical innovation', Journal of Product Innovation Management, Vol. 18, No. 4, pp.231-246.

PDMA (2004) 'The PDMA glossary for new product development', in: K.B. Kahn, G. Castellion, A. Griffin (Eds.) PDMA Handbook, New Jersey: John Wiley \& Sons.

Perks, H. and Moxey, S. (2011) 'Market-facing innovation networks: How lead firms partition tasks, share resources and develop capabilities', Industrial Marketing Management, Vol. 40, No. 8, pp.1224-1237.

Prebble, D.R., de Wall, G.A. and de Groot C. (2008) 'Applying multiple perspectives to the design of a commercialisation process', $R \& D$ Management, Vol. 38, No. 3, pp.311-320.

Rehme, J., and Svensson, P. (2011) 'Credibility-driven entrepreneurship, A study of the first sale', The International Journal of Entrepreneurship and Innovation, Vol. 12, No. 1, pp.5-15.

Reid, S.E. and de Brentani, U. (2010) 'Market vision and market visioning competence: Impact on early performance for radically new, high-tech products', Journal of Product Innovation Management, Vol. 27, No. 4, pp.500-518.

Rogers, E.M. (1983) Diffusion of Innovations, New York: The Free Press. 
Ruokolainen, J. (2008) 'Constructing the first customer reference to support the growth of a start-up software technology company', European Journal of Innovation Management, Vol. 11, No. 2, pp.282-305.

Ruokolainen, J. and Igel, B. (2004) 'The factors of making the first successful customer reference to leverage the business of start-up software company - multiple case study in Thai software industry', Technovation, Vol. 24, No. 9, pp.673-681.

Salminen, R.T. and Möller, K. (2006) 'Role of references in business marketing - towards a normative theory of referencing', Journal of Business-to-Business Marketing, Vol. 13, No. 1, pp.1-51.

Siegel, R.A., Hansén, S.-O. and Pellas, L.H. (1995) 'Accelerating the commercialisation of technology: Commercialisation through co-operation’, Industrial Management \& Data Systems, Vol. 95, No. 1, pp.18-26.

Srinivasan, V., Lovejoy, W.S. and Beach, D. (1997) 'Integrated product design for marketability and manufacturing', Journal of Marketing Research, Vol. 34, No. 1, pp.154-163.

Steen, J., Hanson, D. and Liesch, P. (1998) 'Collaborative research and development: New insights from cyclic models of the innovation process', International Journal of Innovation Management, Vol. 2, No. 1, pp.107-121.

Story, V., Hart, S. and O'Malley, L. (2009) 'Relational resources and competences for radical product innovation', Journal of Marketing Management, Vol. 25, No. 5-6, pp.461-481.

Story, V., O'Malley, L. and Hart, S. (2011) 'Roles, role performance, and radical innovation competences', Industrial Marketing Management, Vol. 40, No. 6, pp.952-966.

Talke, K. and Hultink, E.J. (2010a) 'Managing diffusion barriers when launching new products', Journal of Product Innovation Management, Vol. 27, No. 4, pp.537-553.

Talke, K. and Hultink, E.J. (2010b) 'The impact of the corporate mind-set on new product launch strategy and market performance', Journal of Product Innovation Management, Vol. 27, No. 2, pp.220-237.

Talke, K. and Salomo, S. (2009) 'Launching technological innovations: The relevance of a stakeholder perspective', International Journal of Technology Marketing, Vol. 4, No. 2/3, pp.248-274.

Tolstoy, D. and Angdal, H. (2010) 'Network resource combinations in the international venturing of small biotech firms', Technovation, Vol. 30, No. 1, pp.24-36.

Tschirky, H., Escher, J.-P. and Tokdemir, D. (2000) 'Technology marketing: a new core competence of technology-intensive enterprises', International Journal of Technology Management, Vol. 20, No. 3/4, pp.459-474.

Van Slyke, C., Ilie, V., Hao, L. and Stafford, T. (2007) 'Perceived critical mass and the adoption of a communication technology', European Journal of Information Systems, Vol. 16, No. 3, pp.270-283.

Yin, R.K. (1989) Case Study Research: Design and Methods, Newbury Park: Sage Publications. 


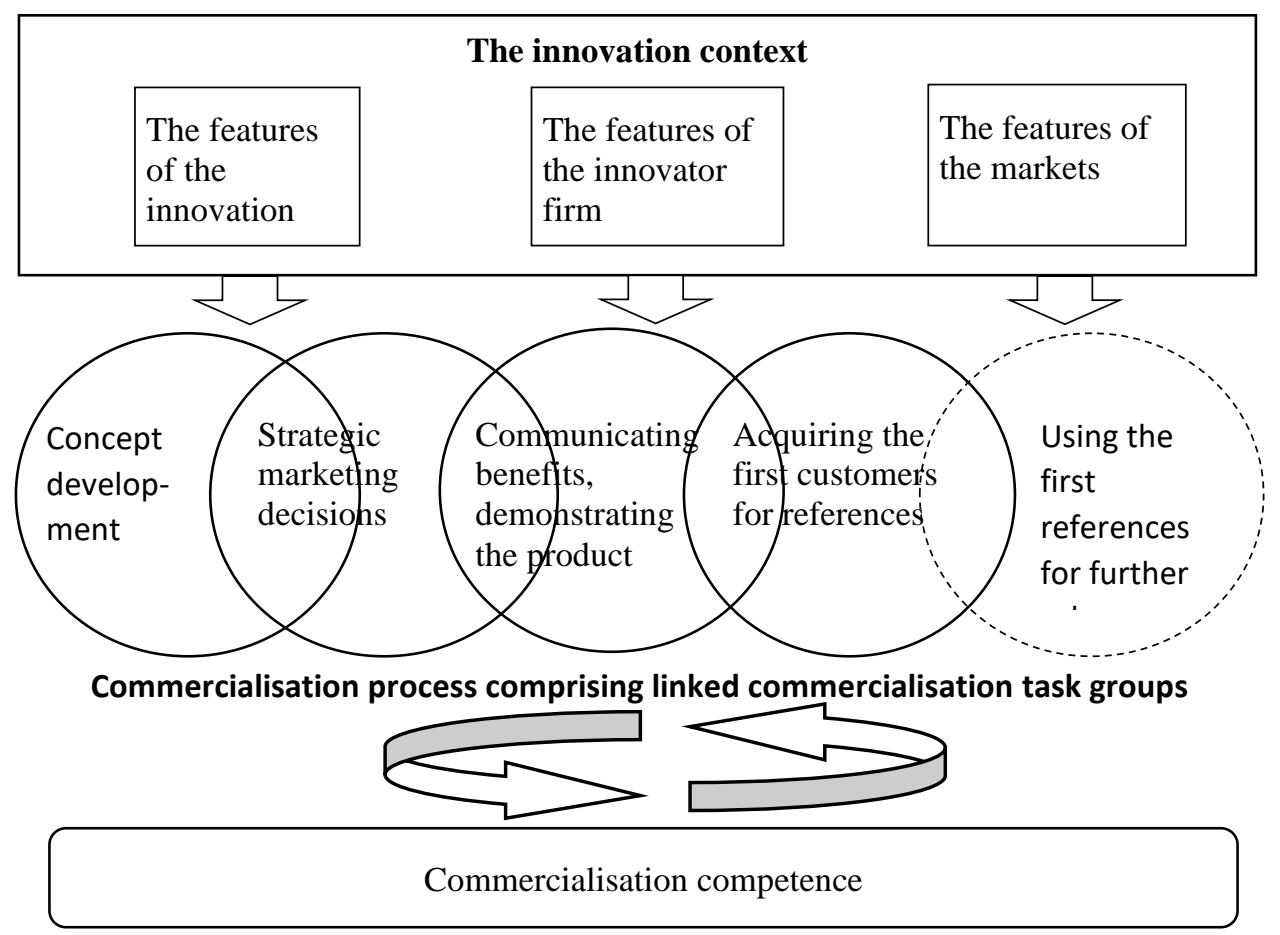

Figure 1 A priori framework for the commercialisation process and the build-up of commercialisation competence 
Table 1 The cases

\begin{tabular}{llll}
\hline $\begin{array}{l}\text { Innovation } \\
\text { industry }\end{array}$ & Invention & Firm & Data \\
\hline $\begin{array}{l}\text { Functional } \\
\text { food }\end{array}$ & $\begin{array}{l}\text { Ingredient that } \\
\text { lowers } \\
\text { cholesterol }\end{array}$ & FirmBen & $\begin{array}{l}\text { Retrospective and real-time } \\
\text { Archival data 1995-2012; interviews 2010-2012 }\end{array}$ \\
High-tech & LED streetlight & FirmLG & $\begin{array}{l}\text { Real-time } \\
\text { Archival data 2009-2012; interviews 2010-2012 } \\
\text { Sports }\end{array}$ \\
$\begin{array}{l}\text { equipment } \\
\text { Equipment for } \\
\text { wigh-tech }\end{array}$ & FirmEx & $\begin{array}{l}\text { Retrospective } \\
\text { Archival data 1995-2012; interviews 2009 }\end{array}$ \\
& $\begin{array}{l}\text { Monitor for } \\
\text { estimating bone } \\
\text { exercise }\end{array}$ & FirmNT & $\begin{array}{l}\text { Real-time } \\
\text { Archival data 2006-2012; interviews 2008-2010 }\end{array}$ \\
\hline
\end{tabular}


Table 2 Cases: Commercialisation process and the build-up of commercialisation competence

\begin{tabular}{|c|c|c|}
\hline $\begin{array}{l}\text { The firm and the } \\
\text { context }\end{array}$ & Synopsis of the commercialisation process & $\begin{array}{l}\text { The build-up of relevant } \\
\text { commercialisation sub-competences }\end{array}$ \\
\hline $\begin{array}{l}\text { Markets: Functional } \\
\text { food ingredient } \\
\text { created a totally new } \\
\text { product category } \\
\text { Innovation: } \\
\text { Consumer product but } \\
\text { B2B relations with } \\
\text { food manufacturers } \\
\text { were important; high } \\
\text { adoption barriers due } \\
\text { to lack of customer } \\
\text { knowledge on health } \\
\text { issues }\end{array}$ & $\begin{array}{l}\text { Firm developed plant stanol ester that lowers cholesterol } \\
\text { and can be added to any food. After product development, } \\
\text { testing and launch in Finland, it entered the U.S. markets } \\
\text { with a large partner, and failed due to legislation } \\
\text { problems and market unawareness of health problems. } \\
\text { Firm repurchased its licenses and developed a new } \\
\text { commercialisation strategy in order to create markets: it } \\
\text { started to recruit licensing partners who add the } \\
\text { ingredient to divergent food products, and to educate } \\
\text { markets with a special Health Care Group. It used } \\
\text { accumulated knowledge and tens of clinical tests in order } \\
\text { to prove the benefits. } \\
\text { By using its first U.S. partner as a reference, the firm } \\
\text { managed to find new partners in Europe and Asia. The } \\
\text { divergent partners were not competitors and therefore } \\
\text { reciprocally shared their increased understanding on } \\
\text { marketing the product. Legislation set boundaries for } \\
\text { partnering because it regulated to which food the } \\
\text { ingredient can be added. }\end{array}$ & $\begin{array}{l}\text { The firm needed to learn to } \\
\text { - Create markets and demand through } \\
\text { customer and partner education > } \\
\text { Market creation competence } \\
\text { - Involve and network with } \\
\text { stakeholders (experts, regulators etc.) } \\
\text { > Stakeholder identification and } \\
\text { mobilisation competences } \\
\text { - Cope with diverse legislation > } \\
\text { Market adaptation competence } \\
\text { - Identify and communicate benefits; } \\
\text { demonstrate the firm's and product's } \\
\text { credibility > Benefit identification } \\
\text { and demonstration competence } \\
\text { - Tackle markets that do not yet } \\
\text { recognize the relevance of the } \\
\text { benefits that the innovation generates } \\
>\text { Stakeholder mobilisation } \\
\text { competence }\end{array}$ \\
\hline
\end{tabular}

\section{FirmLG}

Firm: Small firm with 10 years' experience in consumer LED products

Firm developed streetlights with LED technology which saves on energy and maintenance costs. After product launch, the firm gained its first customers for the first version of the product.

Firm selected municipalities as its end target group because they need to invest in new street lighting systems due to EU legislation. Technical manager delivered many

Markets: Difficult to identify the buying decision maker/the customer; customer suspicious about benefits

Innovation:

Rapidly evolving novel technique added into street lightning; high adoption barriers

FirmEx

Firm: Medium sized

firm with a globally known brand

Markets: No existing markets; high adoption barriers due to embarrassing use of the product; intermediaries hindered distribution

Innovation: New equipment and new sports exercise; perceived as embarrassing expert lectures on the current state of LED technology.

Together with a complementary firm and a non-profit organization, the firm generated the idea of walking poles for exercise.

Decision making and buying is complicated in municipalities. Target groups were more interested in cost savings than quality of light which is one of the key benefits. Moreover, the competitor's failure with a different kind of LED product made the customers suspicious of the technology and reluctant to invest in it.

Following product and concept development, problems started to emerge because retailers were reluctant to display it on their shelves. The actors continued in collaboration, for commercialisation, in order to make the sport attractive to customers and stakeholders. As the major problem was getting people to walk with the poles, partners started to collaborate with sports and health associations, experts, sports clubs and doctors, who communicated the benefits of the sport or demonstrated the use of the product. The media provided publicity by keenly profiling 'the strange new sport'.

Complementary offerings started to emerge. All actors educated and equipped instructors, and built a sports instructor network. Also enthusiastic lead users built awareness, educated other users, and communicated the benefits.
The firm needed to learn to

- Develop a concept and select segments and position > Strategic marketing competence

- Identify and acquire first customers; how to gather user information and experiences, and to use them in further marketing > Reference acquisition competence, benefit communication competence

- Create an understanding of the benefits in the eyes of the customer and demonstrate benefits in a credible way > Benefit identification and demonstration competences

- Identify buying decision makers, convince them and facilitate decision making > Benefit demonstration and communication competence, stakeholder identification competence

The firm needed to learn to

- Tackle markets that do not easily see the benefits of the innovation or adopt the innovation; see what benefits the innovation generates for divergent stakeholders and activate them in order to create markets/whole adoption network; create market pull > Market creation competence; benefit identification, demonstration and communication competences; stakeholder identification and mobilisation competences 


\begin{tabular}{|c|c|c|}
\hline $\begin{array}{l}\text { FirmNT } \\
\text { Firm: Small firm with } \\
\text { sparse resources } \\
\text { Markets: High } \\
\text { adoption barriers due } \\
\text { to lack of customer } \\
\text { and stakeholder } \\
\text { knowledge on bone } \\
\text { health issues; growing } \\
\text { wellness markets } \\
\text { Innovation: } \\
\text { High-tech wellness } \\
\text { product }\end{array}$ & $\begin{array}{l}\text { The firm developed a monitor to estimate the sufficiency } \\
\text { of bone exercise. Osteoporosis is becoming a serious } \\
\text { health factor, the firm could have developed the monitor } \\
\text { to target medical experts or consumers, and chose the } \\
\text { latter since it was pursuing large global markets. } \\
\text { When the firm launched the monitor, the media were very } \\
\text { interested. In order to raise interest in bone issues among } \\
\text { customers and partners, the firm started to create a } \\
\text { network comprising bone-related actors, since the } \\
\text { wellness industries offered a variety of potential } \\
\text { collaborators. The firm's idea was that together the firms } \\
\text { could create markets for bone health offerings and } \\
\text { divergent complementaries to support the } \\
\text { commercialisation of the monitor. } \\
\text { Networking proved difficult for a small and unknown } \\
\text { firm: potential partners were supportive but were not } \\
\text { willing to engage in formal collaboration and many firms } \\
\text { were looking for short-term returns instead of committing } \\
\text { to the common long-term goal of creating bone health } \\
\text { markets. The vague line between competition and } \\
\text { collaboration also complicated the situation and formal } \\
\text { interaction promoting bone health ceased. } \\
\text { In spite of its recognized potential, the monitor did not } \\
\text { break into consumer markets, so the firm changed its } \\
\text { marketing strategy and started to seek e.g. a licensing } \\
\text { partner. }\end{array}$ & $\begin{array}{l}\text { The firm needed to learn to } \\
\text { - Create markets and build awareness } \\
>\text { Market creation competence } \\
\text { - Conceptualise the product for the } \\
\text { targeted market > Strategic } \\
\text { marketing competence } \\
\text { - Identify and mobilise stakeholders > } \\
\text { Stakeholder identification and } \\
\text { mobilisation competences (failed) } \\
\text { - Create and build awareness of the } \\
\text { new phenomenon that encompasses } \\
\text { the invention > Market creation } \\
\text { competence } \\
\text { - Change attitudes towards unwanted } \\
\text { innovation with benefits > Benefit } \\
\text { communication competence (failed) }\end{array}$ \\
\hline
\end{tabular}




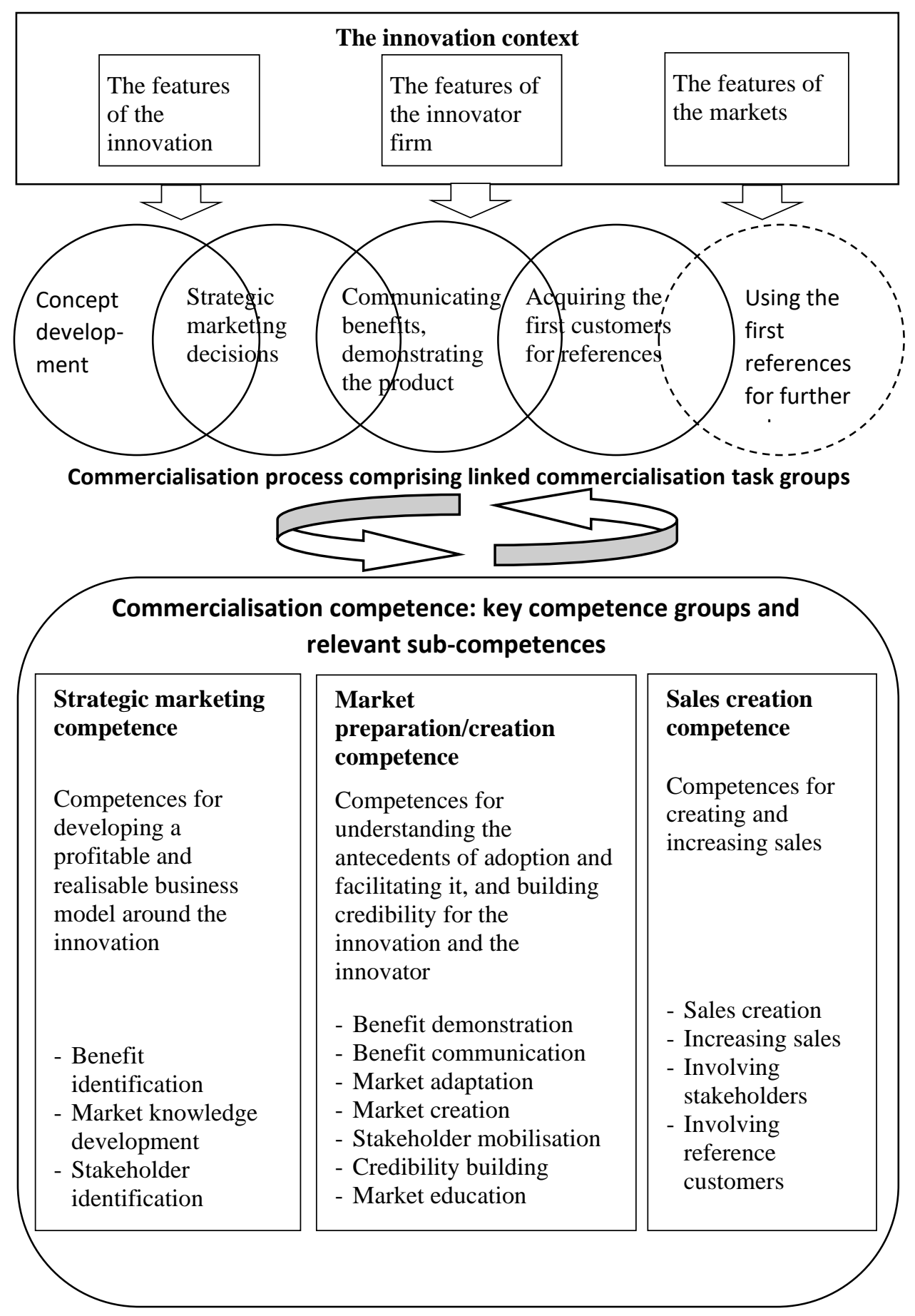

Figure 2 Refined model of the commercialisation process and the build-up of commercialisation competence 


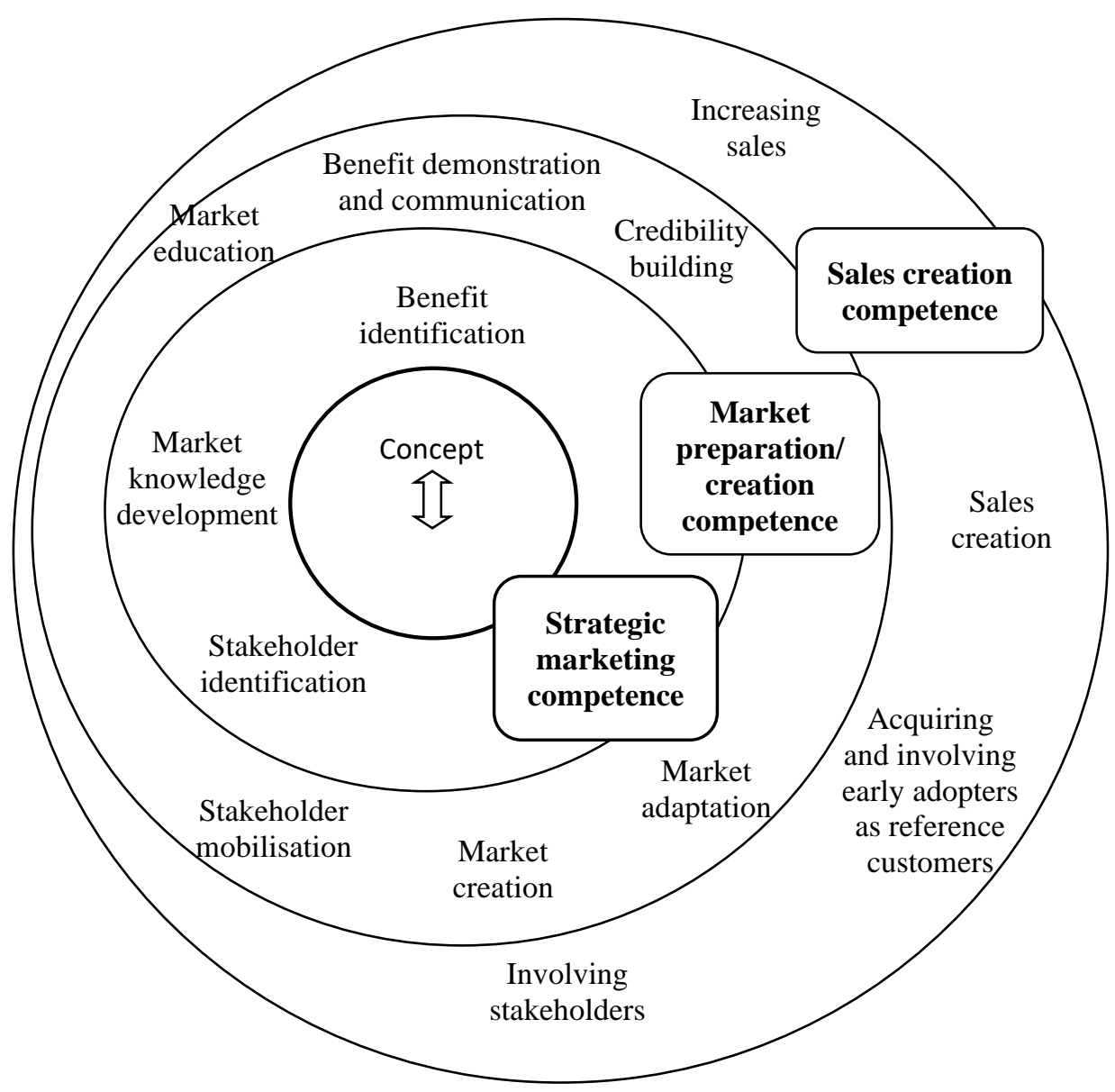

Figure 3 Dynamic model for commercialisation competence build-up 